\title{
'I don't really like tedious, monotonous work'. Working-class young women, service sector employment and social mobility in contemporary Russia
}

\author{
Charlie Walker \\ University of Southampton, UK
}

\begin{abstract}
This article contributes a global perspective to the emerging literature on girlhood in Western contexts by examining the changing shape of transitions to adulthood amongst working-class young women in St. Petersburg, Russia. As in many Western countries, new forms of service sector employment and an increasingly accessible higher education system appear to offer young women new prospects for social mobility. In contrast to the increasingly impoverished and denigrated traditional pathways into work, the young women in the study derive significant value from these new opportunities, constructing narratives of self-actualisation and approximating notions of respectable femininity. Nevertheless, actual social mobility is elusive, as familiar patterns of classed and gendered stratification limit their prospects. Despite its specificity, the case thus further illustrates the limited nature of the transformations available to young women through the new forms of education and work characteristic of global neo-liberal contexts.
\end{abstract}

\section{Keywords}

Class; employment; femininities; gender; neo-liberalism; post-socialism; Russia; service sector; youth transitions

\section{Introduction}

In most Western countries, the changing shape of young women's transitions to adulthood has been the subject of significant attention over recent decades. Reflecting the wider economic shift from manufacturing to service industries and parallel shifts in educational participation, young women's position in the labour market has been transformed, with growing numbers of women in a range of professional and para-professional occupations (Jaumotte, 2003). As Baker (2010) points out, however, these shifts have come to underpin a somewhat mythologised commentary about female success in education and employment, which conceals the persistence not only of significant divisions in men and women's respective career prospects and domestic positions, but also, of enormous social divisions between women. As has been explored in a growing body of literature addressing the experiences of young women in late modern, neo-liberal societies (Aapola et al., 2004; Harris 2004; Walkerdine et al., 2001), divisions of social class and ethnicity continue to be highly salient, despite the increasingly meritocratic discourses shaping the lives of all young people. Indeed, rather than a purported dilution of social divisions, it is the very promise of limitless possibilities and insistence on individual effort and transformation central to neo-liberal societies that has arguably brought about the biggest change in the way in which young women from all backgrounds experience the process of growing up. As levels of female educational and labour market participation have risen and girls' success vis-à-vis boys has become commonplace, all young women have been placed under similar pressures to succeed and to reflect upon their lives through notions of choice and autonomy, regardless of the resources that lie behind their narratives.

The conceptual frame of reference used in this body of literature, like the meta-theories of individualisation and detraditionalisation it draws upon, is relatively broad, referring as it does to processes taking place in 'neo-liberal', 'late modern' societies. Nevertheless, on an empirical level its scope has been limited to Anglo-Saxon countries such as the UK and Australia, whose experience of neo-liberal transformation may, or may not, have been highly specific. By contrast, this article seeks to take a broader view of neo-liberalism, and thus to broaden our theorising about its effects, by exploring the changing shape of young women's transitions to adulthood in post-Soviet Russia, where

\section{Corresponding author:}

Charlie Walker, Lecturer in Sociology, Faculty of Social and Human Sciences, University of Southampton, Highfield, Southampton, SO17 1BJ, UK.

Email: charlie.walker@,soton.ac.uk 
the direction of change in women's prospects has been somewhat different from that seen in the West. While under state socialism women experienced almost universal employment and high levels of educational participation, the post-socialist period has brought much uncertainty for women in countries throughout the former Soviet Union, as the social and economic transformations of the 1990s brought new forms and degrees of gender discrimination. As Ashwin (2000) argues, the early post-socialist period was marked by the emergence of masculinist discourses calling for a reversal of socialist era 'mistakes' in 'gender engineering', with governments and media alike framing the new spheres of business and politics as male spaces, and pressuring for the re-domestication and resexualisation of 'over-emancipated' women. In this context, and in stark contrast to the 'female future' heralded up in the West, women of all ages were under pressure to maintain their position in the labour market, and faced emerging problems of discrimination and sexual abuse in the workplace (Bridger et al. 1996). Alongside matters regarding the treatment of women, the types of opportunities in the new service sector opening up to women in Western countries have been slow to materialise, as post-Soviet economies have been exceedingly slow to restructure and shift away from the dominant manufacturing industries that provided the bulk of employment under state socialism, and the smallscale, 'kiosk capitalism' that characterised the nineteen-nineties (Clarke and Kabalina, 2000).

Nevertheless, two decades after 'transition' began, the opportunity structures characteristic of young women's transitions in the West have begun to materialise in Russia, particularly in major commercial cities such as St. Petersburg, where the present study was based. As in the West, St. Petersburg's educational and labour markets offer a range of pathways into its fast expanding service industries, not least in those areas of the service sector which have been described as demanding more 'aestheticised' forms of labour, and which, in turn, have been characteristically linked with young women (Warhurst et al., 2000; Pettinger, 2005). Against this background, this article examines the ways in which these wider educational and labour market changes are re-shaping transitions to adulthood amongst working-class young women training for a variety of forms of service sector employment.

\section{The working class in Russia's emergent symbolic economy}

The article draws on empirical material from an ongoing programme of research exploring the changing experience of growing up working class in post-Soviet Russia, conducted by the author in the provincial city of Ul'ianovsk in 2004-5 and the 'second capital' of St. Petersburg in 2008. Both the Ul'ianovsk and St. Petersburg studies focused on young people graduating from vocational training colleges (profuchilishcha) and, at the institutional level, were concerned with the ways in which colleges had been able to reorient themselves towards the emerging labour markets their graduates would enter. In Ul'ianovsk, as elsewhere in provincial Russia, a lack of restructuring and general dependence of the local economy on near-obsolete enterprises meant that both young women and men faced difficult prospects, as colleges continued to channel them into low paid, low prestige jobs in the ailing sectors of the old Soviet economy. While young men trained as machine operators and welders for large engineering enterprises, young women mostly trained in gender-typical professions such as sewing and cooking for newly privatised food processing plants and clothing manufacturers:

I worked there for a while but... the wages were just awful... about 900 roubles... These orders that come from England and Germany, we sewed them and stuck labels on that said they were from England - we were just cheap labour. (Irina, 19, Sewing machinist)

The work emerging from this study has mostly focused on the ways in which young people attempted to find alternatives to these 'virtual transitions' into impoverished forms of employment (Walker, 2011). As their narratives suggest, however, it was not only the material impoverishment of factory jobs that the respondents wished to overcome, but also, the deeply etched symbolic impoverishment that appeared to characterise the forms of employment available to them. This sense of worthlessness surrounding manual labour in Ul'ianovsk is indicative of the changing position of manual employment in Russia's symbolic economy, in what commentators have seen as a reversal of Soviet hierarchies of prestige. While, during the Soviet period, workers had been accorded a relatively high social status, in post-Soviet Russia, as elsewhere in the post-socialist world, both working-class people and the forms of employment they are engaged in have come to be discursively constructed as 
backward, meaningless, and ultimately superfluous. In Romania, for example, Kideckel (2008: 30), describes a shift in the symbolic position of miners and industrial workers 'from veneration to denigration', such that 'workers either disappear from national media altogether, or appear only as unrecognisable caricatures'. In their Russian variant, such caricatures have emerged on 'hate websites' delighting in the portrayal of working-class young men and women as gopniki/gopnitsipejorative terms which construct working-class youth as a backward, illiterate mass inhabiting outlying districts of provincial towns (Stephenson, 2012). Indeed, the embodied images of drunken young men and sexualised young women that constitute the bulk of material on websites such as gopstop.org and bidla.net have particular relevance for the social positioning of vocational college students, as such sites use gopniki/gopnitsi interchangeably with the words PTUshniki/PTUshnitsi, terms deriving from the Soviet acronym for vocational training college.

\section{Self-invention, class and gender}

A number of commentators have argued that such forms of denigration constitute a backlash against the privileges held by workers in the socialist period (Lampland 2000; Rivkin-Fish 2009). However, as Stenning (2005) argues, the position of the post-socialist working class should be understood in terms not only of the 'end of socialism', but also, of the wider social and economic shifts - most notably, the shift towards individualisation - that are purported to have brought about the 'end of work' and the 'end of class' in Western societies. Indeed, in the late modern, consumer-driven societies of the West, it is precisely the shift towards neoliberal values of individual autonomy, choice, and self-determination that have repositioned the working class as somehow lacking and inadequate. In Bauman's (1998) terms, the othering of working class lives as abject would appear to be a necessary corollary of what he sees as the elevation of 'aesthetic' sensibilities and modes of engagement over the more routine and monotonous forms of social integration characteristic of the 'first' modernity. As choice-making and individualised performance become central to the valuing of all forms of social activity - including employment - those at the lower ends of the consumer and labour markets cannot but be seen as abject, poor consumers. Bauman's emphasis on the centrality of choice to value resonates with a range of other theories pointing to the changing nature of social biographies under conditions of neoliberalism, some of which appear more optimistic about the prospects these changes open up. Giddens' (1991) concept of the 'reflexive self', and Beck's (1992) argument that 'normal biographies' have been replaced by 'choice biographies', for example, frame the need for social actors to become self-reliant, self-sufficient, self-inventing subjects both as a compulsion and as an opportunity, a potential liberation from traditional social constraints. As a number of commentators have argued, however, while apparently predicated on the death of class, the 'subject of value' at the heart of the neo-liberal project is made in the image of the middle class, such that the working class is its necessary 'other' (Walkerdine, 2003; Savage, 2003; Skeggs, 2005, 2011).

Alongside perspectives exploring the continuing salience of social class, the limitations and consequences of neoliberalism's demands for and promises of self-invention have similarly been argued from a gender perspective, not least in relation to the 'successful girls' discourse popular in the West. As Adkins (2001) argues, while young women are portrayed as the winners in late modern capitalism, the cultural feminisation of the economy has not led to a straightforward detraditionalisation of gender from which women have directly benefitted. Rather, the tendency to naturalise women's performances of femininity in service sector roles can actually fortify rather than erode traditional systems of domination. Studies exploring the impact of new educational opportunities on young women's prospects have been similarly sceptical, particularly when addressing intersections of gender and class. As Walkerdine (2003: 240) argues, both the broadening of participation in higher education and the growth of service sector employment 'appear to offer possibilities and lifestyles which are tied up with what is traditionally regarded as middle-class status', such that social mobility is increasingly seen as an expectation or even a necessity rather than simply an aspiration. However, the working-class young women in her study of youth transitions in the UK are unable to escape gender-typical positions in the lower reaches of the service sector, despite the language of choice and individual autonomy that pervade their narratives (Walkerdine et al. 2001). Similarly, the experiences of Baker's (2010: 13) respondents in Australia indicate that, despite ostensible access to unprecedented choice, 'new possibilities for young women are still located within traditionally gendered and classed parameters'. 
Discussing what they see as the necessity of 'constant and perpetual self-invention', Walkerdine et al. (2001: 9-10) argue that their respondents' experiences 'reflect a global trend... [that] no country is escaping'. But to what extent may we discern similar processes in the more peripheral contexts of neo-liberalism? The present article draws together perspectives on class, gender and self-making in arguing that a similar picture is apparent in post-Soviet St Petersburg, as narratives of individual autonomy and self-invention dominate young women's narratives, despite the elusiveness of any 'real' social mobility. In a context in which manual labour and the working class in general are increasingly denigrated, new forms of work and education in St. Petersburg appear to offer young women the opportunity to 'reinvent themselves', at once inviting and demanding them to play out the 'compulsory individuality' (Skeggs, 2005) identified in Western countries. While providing a site upon which to construct valued subject positions, however, the new educational and labour market structures appear limited in the extent to which they enable the respondents really to overcome familiar disadvantages rooted in class and gender. The following section outlines the nature of the data produced by the study.

\section{Methods and data}

The article is based primarily on a case study conducted in the city of St. Petersburg in 2008, with some reference made to the earlier study in Ul'ianovsk in 2004-5. While Ul'ianovsk, a mature but declining industrial region, was ideal for exploring processes of deindustrialisation, St. Petersburg's status as a rapidly developing metropolis provided an opportunity to examine the ways in which young people's prospects were being shaped in a context of economic growth and expansion. In the period just before the world economic slump beginning in 2008, St. Petersburg had unemployment levels significantly lower than the Russian average ( $2 \%$ against $6.3 \%$ nationally) and a fast-expanding service economy (Goskomstat, 2011).

As in Ul'ianovsk, the research was conducted in a range of vocational colleges (profuchilishcha, litseya, kolledzhy) within Russia's Initial Vocational Education and Training (IVET) system, which traditionally has trained students from working-class and rural backgrounds for manual occupations in local industries. While their working-class profile has historically given them a reputation for attracting the 'least able' and 'least disciplined' children (Matthews 1982: 87-8), IVET colleges appear to have been undergoing their own 'reinvention' in recent years, in two principal respects. First, while continuing to offer strongly gendered forms of training (commonly using the terms 'male' and 'female professions'), the five colleges in St. Petersburg in which young women were interviewed had to varying degrees shifted the courses they provided for young women away from the traditional 'female subjects' in manufacturing (predominantly sewing and cooking) towards a variety of forms of 'interactive service work' (Pettinger, 2005). This shift was most evident in the growth of subjects such as hospitality and tourism management, but also included the expansion of beauty-related subjects such as hairdressing and fashion, and was evident across the IVET sector in the city (Sidel'kovskii, 2007). Second, the colleges in the study - Nevskii College of Tourism, Petropavlovskii Technical College, Vyborgskii College of Fashion, Profuchilishche 79 and the Railway College ${ }^{\mathrm{i}}$ - had developed varying degrees of links with newly established higher education institutions (HEIs), which offered similar disciplines at a higher level, again reflecting a wider tendency for young people from all backgrounds in Russia to undergo extended periods of participation in further and higher education (Walker, 2011). Thus, the colleges in St. Petersburg had taken a significant leap from their identity as base level institutions training a heavily localised, working-class intake of students for the lower rungs of the manufacturing sector, and were presenting themselves as institutions offering a route into higher education and possible careers as service sector professionals.

In total, biographical interviews were taken with 34 young women aged 18-27 who were either studying in or had graduated from one of the five colleges. Reflecting course provision, the bulk of respondents were training for forms of interactive service work, with a small number training as cooks and sewing machinists. In terms of social background, the group of young women interviewed for this research were largely typical of the IVET sector, with one or both parents employed in manual labour of some kind, while a handful of respondents came either from less privileged backgrounds (brought up by grandparents in the absence of parents, for example) or from families in which parents worked as professionals with higher education. Respondents were recruited through teachers, who were asked to invite current and past students from any courses at the colleges to volunteer for interviews. The 
inclusion of graduates as well as final year students was intended to provide a longer view on young women's transitions by allowing comparisons to be made between the plans and prospects of younger respondents and the experiences of older respondents who had been in a similar position a few years earlier. Interviews were semi-structured and explored respondents' past experiences and future plans in relation to key transitions in education, training, employment and family. They were carried out predominantly in empty classrooms and offices in respondents' colleges and workplaces, and were supplemented by additional ethnographic material such as everyday observations in and around these sites.

\section{Performing valuable selves through interactive service work}

Almost without exception, and in stark contrast to their counterparts in Ul'ianovsk training as sewing machinists and food processing technicians, young women training in service professions in St. Petersburg were entirely positive about the prospect of pursuing careers in their chosen areas. This was despite the fact that, as will be discussed below, none of them expected to earn high salaries. Rather, the young women's enthusiasm for service sector work stemmed from less tangible factors, namely, the opportunities such careers provided for the construction of valuable notions of selfhood, subject positions which derived their value from the range of performances and distinctions enabled by interactive service work.

The first respect in which the young women embraced work in the service sector was in relation to the performances of femininity it involved. As Leidner (1991: 174) argues, the specific characteristics of different forms of employment do not in themselves determine whether they will be seen as more or less suitable for men or women, but rather, the features of a job act as 'resources for interpretation' by workers, such that men, for example, may emphasise the masculine components of a job which is culturally constructed as feminine. In the present research, the demands of the jobs the respondents were training for easily fitted into dominant cultural constructions of the skills and attributes that have traditionally been central to 'women's work', such as the ability to communicate with and provide services to clients (Britten, 2000: 429), and it was these gendered components of interactive service work that were most easily identified by respondents as attractive features of their professions:

Well, it seemed interesting to me... to communicate with people, it's something I enjoy. Like, hospitality service, all the time it's people, people, contact (Katya, 18, tourism and hotel service)

I don't know how to explain it... I get satisfaction from the fact that, you do something and you please someone else... I mean, you create something, and people try it, and they like it - of course it's nice, right? (Veronika, 26, tourism and hotel service)

The main thing is communication with clients, when people come in, you smile at them, and they ask you for help with something. I really like that (Masha, 18, hospitality administration)

Some were more explicit in identifying their work as 'suitable' for a woman:

For us, for girls, it's better to go into something where you work with people than something physical... (Katya, 18, secretary-PA)

The respondents' ability to 'buy into' the jobs they were training for was clearly tied up with their interpretation of those jobs - either explicitly or implicitly - as congruent with an 'appropriate' form of gender enactment. As a number of commentators have argued, our ability to recognise ourselves as performing gender appropriate roles at work shapes whether we see our employment as stigmatising or valorising, or as worthy or unworthy of our effort (Robinson and Hockey, 2011, for example). Nevertheless, the gender appropriateness of interactive service work for young women needs to be understood in relation not only to more masculine forms of employment, but to a range of other gender appropriate work along a scale of more or less acceptable femininities. Working as a sewing machinist in a clothing factory, for example, easily fits into a feminine gender idiom surrounding women's 'natural' skills and roles (see, for instance, Bank Muñoz, 2008), but constitutes a stigmatised subject position in contemporary Russia. During the Soviet period the female industrial worker had symbolised a notion of femininity - promoted by magazines such as Rabotnitsa (Woman Worker), and Sovetskaya Zhenshchina (Soviet Woman) - centering equally on productive labour and motherhood in 
service to the state, and, although not actively discouraged, female beauty was positioned as largely secondary (Gradskova, 2007). In post-Soviet Russia, as in post-socialist China (Otis 2011), dominant representations of women have replaced this strong female industrial labourer with a softer, 'emphasised' femininity (Connell 1987), which surpasses its Western counterparts. As Otis (2011: 51) finds, it is the dominance of more essentialist representations of women that underpins the performances of femininity required from female hospitality workers in contemporary China, reflecting a more extreme and exploitative version of the demands for the performance of aesthetic labour placed on women in interactive service work in the West (Warhurst et al.2000; Nickson and Korczynski, 2009; Pettinger, 2005).

As Otis (2011: 161) also finds, however, although forms of interactive service work may be exploitative, they may also offer opportunities for the construction of 'respectable' subject positions, as young women from working-class backgrounds are required to embody and perform idealised versions of middle-class femininity in the fulfillment of their roles. Such constructions of femininity were widely evidenced at the colleges, both in the glossy images of 'professional women' used in marketing materials, and, at the tourism college, in photographic displays of extra-curricular events such as 'Miss Hospitality' competitions and etiquette masterclasses. In the Russian case, the appeal of such femininities must be seen against the background not only of the outdated rabotnitsa, but also, of the overtly sexualised gopnitsa, whose image potentially positions all working-class young women as utterly lacking in value. In this context, and notwithstanding the dangers posed by the more overt sexualisation of some forms of service work, young women in St. Petersburg embraced the opportunity to engage in employment that was both more congruent with dominant notions of 'emphasised' femininity, and provided an outlet for the construction of respectable selves.

Studies of employment relations within interactive service work have on the whole said little about what employees gain from their jobs, highlighting instead the essentially exploitative manner in which employers profit from the variety of forms of capital their employees bring to the service encounter, or the ways in which employees are required to enact bodily practices initiated 'from above'. Hochschild (1983) for example, points to the selling of emotional labour by air stewardesses, while Adkins' (1995) study of hospitality workers finds young women to be required to use their bodily capital for a variety of sexualised performances. More recently, Pettinger (2005) argues that retail workers are employed not only for their physical appearance, but also for the cultural and social capital they embody, which in turn is subsumed into the image of the brand being sold to customers on the shop floor. However, alongside these exploitative dimensions, it is also crucial to recognise the position of these forms of labour within workers' biographies and their own struggles for recognition by highlighting the ways in which workers themselves derive forms of capital (other than wages) from their employer, and use this capital in the construction of valued subject positions. Alongside Otis (2011), an exception in this respect is Skeggs' (1997) study of women care workers, whose 'caring selves' are central to their attempts to deflect, through the mobilisation of their symbolic capital (as 'caring people'), the moral judgements that working-class femininity has historically attracted. In the same way, interactive service workers may be seen as deriving value from the various forms of symbolic capital and prestige that are attached to a given employer within a particular cultural milieu. Indeed, insofar as aesthetic labour presupposes that workers embody, or at least perform, the values and identity of the company they work for, it follows that interactive service work is especially likely to provide opportunities for 'passing' (Skeggs, 1997). For young women training to be hospitality workers in St. Petersburg, for example, five-star hotels of 'western standard' occupied a lofty position within the symbolic economy of the city, making employment at these organisations highly desirable:

They sent us on practical training, me and my class mates, to places like hotel Europa and Radisson Hotel...4 star, 5 star hotels... I was in Europa - a beautiful hotel! ... it's the same level as hotels abroad... it's connected with an English company, an American company, I can't remember exactly... (Irena, 18, hospitality administration)

As this example illustrates, associations with the West can carry enormous symbolic capital in Russia, not least amongst young people (Pilkington et al., 2002). Such associations could consist in actual connections with the West (specific hotels or potential opportunities to travel in a future work role) or in the symbolic links evoked by russified versions of English words (menedzhery, salony). Similarly, the exclusivity of prospective employers within the emergent consumer market could act as an 
important marker of distinction - something most obvious in the ways in which trainee hairdressers distinguished between 'ordinary hairdressers' (parikhmakhery) and 'stylists' (stylisty):

I: So are there any specific salons where you would like to work?

R: Yes... but they told me that before getting a job there you need experience in an ordinary salon.

I: An ordinary hairdresser?

R: No, a salon. Not a hairdresser, a salon. To get a job on Nevskii [Prospekt], next to Moscow station, you need three years of experience and only in a salon (Marina, 18, hairdresser)

[In salons] they don't have hairdressers, they have stylists... In an ordinary hairdressers of course [they] try to do everything properly, but there's no creativity (Natalya, 18, hairdresser)

As this last quotation indicates, a further mark of distinction came from the apparent necessity for respondents to obtain jobs that allowed them to exercise creativity and, more pointedly, to express their individuality. It was in this respect that the respondents' narratives about their future careers were most distinct from those of their counterparts in Ul'ianovsk, where the predominance of jobs in large-scale manufacturing precluded these kinds of identification. The way young women in the present study framed their future working lives was suggestive of the 'compulsory individuality' now demanded for the construction of 'valuable selves' (Skeggs 2005), such that jobs were described as desirable only insofar as they facilitated a process of 'becoming', and more 'static' jobs were not worth doing:

I: So would you prefer to work in a restaurant then, or a canteen?

R: In a restaurant there'd be new things. I mean, there'd be some new menu, something that you came up with. You could, like, really discover yourself... you could invent something new. But in a canteen, it'd all be the same thing... it's just not interesting (Lida, 18, chef)

Indeed, for those whose training would traditionally have led them into factory work, it was the lack of opportunity for 'creativity', 'self-discovery' and 'self-realisation' that was the most clearly articulated reason for not taking such jobs: alongside the embodiment of un-femininity in the figure of the rabotnitsa and the symbolic impoverishment of the factory compared with modern, Western-style hotels, offices and salons, factory jobs denied the possibility of individuality. Trainee sewing machinists at the College of Fashion, for example, which had historically provided young machinists for the clothing manufacturers of the city, planned to work for tailors, or as fashion designers or specialist outfitters of some kind, and considered factory jobs only as a last resort:

I: Would you consider working in a factory?

R: No! I don't really like tedious, monotonous work, and in factories you're always doing the same thing. There's no, like, creativity. (Albina, 19, catering management)

If it's an absolute last resort.. if there are really no other options then I could work there [Kati, a local clothing factory]. The wage is ok... it's just that sort of place... it's like, you have to sew the same things constantly, pants, standard skirts, standard blouses... Like, it's boring for me just to sew pants. (Yulia, 18, tailor)

Indeed, in one respondent's account of a practical training placement, the perceived monotony of factory work was personified in the shape of older workers actually preventing unauthorised shows of initiative:

The first placement we had, on Lenin Square, we had a conflict there. I'd already finished sewing - it was a production line - and I'd finished and wanted to try sewing something else, but then some of the workers [rabotnitsy] shouted 'no! stop!', and we had to leave (Nastya, 18, tailor)

The young women's attitudes towards factory work were further reflected in a visit to the Soviet-era clothing manufacturer Bolshevichka, which until recently had had a long-running relationship with the Fashion College, but currently employed only two machinists under the age of thirty, both of whom were economic migrants from the Baltic states.

Thus, in respondents' narratives about current and future job prospects, the distinctions they made between older and newer forms of work were reflective of wider perceptions of value that went beyond practical matters of pay and conditions. Both the substantive content of careers in the service sector, and their superficial, aesthetic qualities, carried a significant degree of symbolic capital for the 
respondents, allowing for performances of a respectable femininity and of individuality and creativity: they were intrinsically interesting and attractive where factory jobs were dull. In this way, the new employment prospects held out possibilities for self-invention that were embraced by respondents.

\section{Realising social mobility: navigating education and labour markets}

Alongside new forms of employment, central to the respondents' future plans were the new opportunities emerging in the educational sphere, with only a handful of respondents not pursuing some form of qualification beyond the IVET level. As mentioned above, most IVET colleges in the city now have preferential routes into partner institutions, which offer courses in both secondary vocational (SVET) and higher education. Those training for employment in the tourist and hospitality sectors, for example, were almost uniformly taking up degree level courses at the Baltic Institute of Hospitality or the University of Service and Economics, which, as well as offering courses at relatively affordable rates, were clearly very attractive options:

One of the most important factors in choosing a higher education institution is the labour market demand of different professions. According to statistics, amongst the most lucrative and promising professions in Russia are those within the service sector, and in the next ten to fifteen years specialists with higher education in this area will be actively in demand. (State University of Service and Economics, 2012).

The attractiveness of these new institutions was further underpinned by the fact that they often shared the same campus and the same lecturing staff as their IVET partner, with some institutions even allowing students to take part-time degree level courses in parallel with their IVET education, providing what one respondent aptly described as an 'economy of time'.

The institutionalisation of different levels of education within the same establishments reflects the massive expansion of higher education in Russia, which has shifted from being a relatively exclusive pathway to a fully-developed and easily accessible (in terms both of price and entrance) mass market of educational services (UNDP, 2004). Reflecting its ubiquity, the prospect of not acquiring higher education was as anathema to respondents as settling for basic level manufacturing jobs, with the majority conveying a need to credentialise themselves as much and as quickly as possible. On the one hand, this was framed as a defensive strategy, as it was felt that, although the titles of service sector qualifications at the IVET level pointed to roles as menedzhery in various different spheres, such qualifications on their own would be almost worthless on the labour market, serving only as basic, entry-level qualifications:

With IVET education, if I go into a hotel, then they're never going to promote me above chambermaid. But if I've got, say, specialised education [SVET or higher], then there's the possibility of career growth. (Vika, 18, tourism and hotel service).

On the other hand, as well as promising 'career growth', higher education clearly held out significant symbolic capital for respondents, despite its massification:

You have to get higher education nowadays. They ask for higher education more than vocational education... and without higher education, well.. people just don't respect you much [ne tak osobo uvazhaiut], put it that way! (Anya, 18, tailor)

As such, like the pursuit of interesting jobs with prestigious companies, the acquisition of higher education was as central to respondents' constructions of respectable and valuable selves as it was to their future plans. Indeed, these two strands of respondents' strategies were inextricably connected, such that achievements in the educational sphere could be considered to map directly onto the prestige of one's future employment:

... it's like, if I go into some hotel, like, a smaller one, one or two stars, then maybe they'd take you [without higher education]. But if you go into, say, a five star hotel, where the workforce is more qualified, then I don't think they'd take someone with IVET education (Olga, 18, hospitality administration).

Respondents thus strongly associated success in the labour market with individual achievements in post-compulsory education. Indeed, some respondents even subscribed to notions of continual development through education and the need constantly to upskill oneself: 
I don't want to stand in one place, I want to develop further. I don't want to just stop at what

I've achieved... To get an education, doesn't mean that you get it and just stop, like a limit. (Veronika, 26, tourism and hotel service)

However, while there was a strong commitment to and belief in the efficacy of further qualifications, it was less clear how much these would actually lead to rewards in the labour market of the type advertised on university websites. As Baker (2010) also finds in her Australian case study, in many cases respondents appeared not to possess the cultural capital required to navigate the complexities of the emerging education and labour markets - what Bourdieu (1984: 154) called the 'fuzzy classifications and blurred edges' of the new system - such that current plans were weakly linked to imagined futures. Lena, for example, was studying psychology at the same time as training to be a secretary at Profuchilishche 79:

My diploma won't be Russian, it will be European, so with this diploma, the reason why it's good, is because I could also go to England, like, I could move there... and they would take me with pleasure, with open arms, as a psychologist, because I'll have a European diploma (Lena, 18 , secretary-PA)

In contrast to this, some respondents tended towards a more pessimistic appraisal of what awaited them in the labour market, acknowledging the difficulties they were likely to face in realising their plans:

R1: The best thing at the moment is for us to get our education... to get more educational qualifications and to get a position as a manager [in a tourist firm]. Although at the same time, you know, once we've got our education it's not a fact that we'll get a job

R2: It doesn't give you any guarantees at all. (Dasha and Sveta, 18 and 19, tourism and hotel service)

Pathways between the new forms of education and employment were indeed by no means certain, not only because of the questionable worth of qualifications from newly established higher education institutions (UNDP, 2004), and the numbers in which respondents were acquiring them, but also because of the manner in which the labour market operated. As has been found in studies of the Russian labour market as a whole (Gerber and Mayorova 2010, for example), possessing the right contacts was seen to be crucial to entering 'good' jobs:

R2: Everything depends on..

R1: on contacts. Because if you've got, like, relatives or friends in a tourist agency...

R2: they'll take you as a manager straight away..

R1: Yeh... it's like that everywhere at the moment... if you turned up and you were like, no one, then you could get a job there as like...

R2: A courier.

R1: A courier or something... It's really tough, because there, especially in these big companies like 'Riviera'... it's like, mum for daughter, daughter for granddaughter...

R2: yeh, relatives are everything.

(Dasha and Sveta, 18 and 19, tourism and hotel service)

Indeed, as well as lacking the cultural capital necessary to navigate the new market of education, respondents rarely possessed the social capital necessary to make significant inroads into the types of opportunity their chosen careers appeared to promise. In this respect, social class was as salient in shaping respondents' outcomes as it was their subjectivities. As has been found in other studies of the labour market in Russia (Tartakovskaia and Ashwin, 2006; Walker, 2011), the pervasiveness of informal relations in hiring practices had a deleterious effect on prospects for social mobility, with only respondents from better educated, professional backgrounds appearing to 'make it'. Nastya, for example, had received help from her mother - a higher-educated manager in a tourist agency - in establishing her fledgling career:

I work with my mother in a tourist company... I worked for one year as a courier, then an assistant manager, then manager for Leningrad region... nowadays I work more in the advertising department, it's more interesting for me (Nastya, 19, tourism and hotel service). 
For other respondents, a combination of more individualised methods - developing contacts whilst on practical placements, direct approaches to employers and, occasionally, job advertisements - could be relied upon to get entry-level jobs, which may eventually lead to the futures they were imagining. However, even amongst the more successful respondents, earning prospects across the various forms of interactive service work the young women were training for were poor, and especially so in the tourist sector, where women's salaries nationally were 39.2\% lower than men's over the period 200511 , against an average gender pay gap of $37 \%$ (Rosstat, 2012). Amongst tourist sector trainees in the present study low wages relative to men were an expectation, and offered some explanation as to why there were practically no young men studying alongside them. Ekaterina, the general manager of a small commercial operation attached to Nevskii Tourist Kolledzh, summed up the gender composition of the sector she had worked in for eight years:

I'd say probably $70 \%$ are women... It's like, men, they're either... general or commercial directors, although you do occasionally see ordinary managers, but not many... I don't know what the reason is, I just think that, in this business, it's like, not very good in terms of wages, it's low-paid... For a woman it's kind of enough, but... to be honest, men have to earn more, and in this business, you're not going to earn a lot here. (Ekaterina, 28, tourism and hotel service)

Indeed, the notion that men 'had to' earn more reflected the wider re-traditionalisation of gender roles in Russia (Ashwin, 2000), according to which young men are expected not only to be the main breadwinner when they start a family later in their twenties, but also, to be the main contributor to the lifestyle of a young couple:

I: So, maybe young men want to earn more?

R: Of course!

I: Of course? So it's not so important for girls?

R: No, but you understand... a girl can anyway find herself a guy who's going to look after her... and, well you understand yourself, for a man to earn 7000 [roubles - 160 Euros]... well, it's just funny!... You couldn't do anything! (Sveta, 21, tourism and hotel service)

These sentiments, which reflected not only the gendering of expectations, but also their implicit heteronormativity (Stella, 2013), were echoed across the different professional groups of respondents, and indicated the extent to which interactive service work and the new educational forms attached to it would bring the young women in the research any 'real' social mobility. While the respondents and their colleges appeared successfully to have re-invented themselves, their prospects in the labour market were indelibly marked by the disadvantages of class and gender, and strongly echoed the tendency, identified elsewhere (Charles and Grusky, 2004), for women to be ghettoised into a narrow range of dead-end occupations.

\section{Conclusion}

This article set out to explore the changing shape of transitions to adulthood amongst working-class young women in contemporary St. Petersburg and the transformations of class and gender that surround their experiences of emerging education and labour markets. In some respects, the cultural specificities of the Russian case make young women's experiences rather different from those outlined in similar studies in the West. In particular, respondents' awareness of structural barriers in the labour market, especially in regard to largely naturalised forms of gender discrimination, was in stark contrast to the sometimes 'invisible' nature of such structures in interpretations of young women's subjectivities in Western contexts (Baker, 2010, for example). At the same time, however, this awareness co-existed with narratives of 'self-realisation', individuality, and autonomy characteristic of the core countries of Western neo-liberalism. These narratives were especially rooted in individual engagements with an increasingly massified higher education system, but also reflected the impoverishment of the old massified transition to adulthood - into women's work in manufacturing - and, relatedly, the wider denigration of the post-socialist working class. In this context, the achievement of some form of social mobility was not simply an option, but was compulsory, and the new service sector and education market provided the forms of capital to make such mobility possible, at least symbolically. The new pathways were prestigious, interesting and creative where old pathways were tedious and monotonous, and were in keeping with notions of an 
emphasised, but respectable, femininity. In material terms, however, social mobility remained elusive, as wider structures of class and gender were repopulated rather than overcome. Indeed, in a national context in which social mobility has practically halted (Gerber and Hout, 2004), the contrast between individual narratives of mobility and wider patterns of stratification that is increasingly characteristic of Western neo-liberalism (Walkerdine 2003) is especially pronounced in post-Soviet Russia.

${ }^{1}$ The names of colleges, major employers and respondents have been changed.

\section{Acknowledgements}

I would like to thank Susan Halford, Pauline Leonard, Elena Minina, the two anonymous reviewers, and members of the Sociology Seminar at the University of Surrey for their helpful comments and suggestions.

\section{Funding}

The research on which this article is based was funded as part of a Postdoctoral Fellowship with the Centre for East European Language-Based Area Studies and St. Antony's College, the University of Oxford

\section{References}

Aapola S, Gonick M and Harris A (2004) Young Femininity: Girlhood, Power and Social Change. Basingstoke: Palgrave.

Adkins L (1995) Gendered Work: Sexuality, Family and the Labour Market. Buckingham: Open University Press.

Ashwin S (2000) (ed) Gender, State and Society in Soviet and Post-Soviet Russia. London: Routledge.

Baker J (2010) Great expectations and post-feminist accountability: young women living up to the 'successful girls' discourse. Gender and Education 22(1): 1-15.

Bank Muñoz C (2008) Transnational Tortillas: Race, Gender, and Shop-Floor Politics in Mexico and the United States. Ithaca: Cornell University Press.

Bauman Z (1998) Work, Consumerism and the New Poor. Buckingham: Open University Press.

Beck U (1992) Risk Society: Towards a New Modernity. London: Sage.

Bourdieu P (1984) Distinction: a Social Critique of the Judgement of Taste. London: Routledge and Kegan Paul.

Bridger S, Kay R and Pinnick K (1996) No More Heroines? Russia, Women and the Market. New York: Routledge.

Britten DM (2000) The epistemology of the gendered organisation. Gender \& Society 14(3): 418-34.

Charles M and Grusky D (2004) Occupational Ghettoes: The World Segregation of Women and Men. Stanford, CA: Stanford University Press.

Clarke S and Kabalina V (2000) The new private sector in the Russian labour market. Europe-Asia Studies 52(1): 7-32.

Connell RW (1987) Gender and power. Stanford: Stanford University Press.

Gerber T and Hout M (2004) Tightening up: declining class mobility during Russia's market transition. American Sociological Review 69(5): 677-703.

Gerber T and Mayorova O (2010) Getting Personal: Networks and Stratification in the Russian Labor Market, 1985-2001. American Journal of Sociology 116(3): 855-908. 
Giddens A (1991) Modernity and Self-identity: self and society in the late modern age. Oxford: Polity Press.

Goskomstat (2011) Regiony Rossii. Sotsial'no-ekonomicheskie pokazateli-2011g. Available at: http://www.gks.ru

Gradskova Y (2007) Soviet People with Female Bodies: Performing Beauty and Maternity in Soviet Russia in the Mid 1930-1960s. Stockholm: Stockholm University Press.

Harris A (2004) Future Girl: Young Women in the Twenty-First Century. London: Routledge.

Hochschild AR (1983) The managed heart: Commercialization of human feeling. Berkeley, CA: University of California Press.

Jaumotte F (2003) Female labour force participation: past trends and main determinants in OECD countries. OECD Economics Department Working Papers 376.

Kideckel D (2008) Getting by in Post-Socialist Romania: Labor, the Body and Working-Class Culture. Bloomington: Indiana University Press.

Lampland M (2000) Afterword. In: Berdahl D, Bunzl M and Lampland M (eds) Altering states. Ann Arbor: University of Michigan Press, 209-18.

Leidner R (1991) Serving hamburgers and selling insurance: gender, work, and identity in interactive service jobs'. Gender and Society 5(2): 154-177.

Matthews M (1982) Education in the Soviet Union: policies and institutions since Stalin. London: Allen and Unwin.

Otis E (2011) Markets and Bodies: Women, Service Work and the Making of Inequality in China. Stanford: Stanford University Press.

Pettinger L (2005) Gendered work meets gendered goods: selling and service in clothing retail. Gender, Work and Organization 12(5): 460-78.

Pilkington H, Omel'chenko E, Flynn M, Bliudina U and Starkova E (2002) Looking West? Cultural Globalization and Russian Youth Cultures. Philadelphia: Pennsylvania State University Press.

Rivkin-Fish M (2009) Tracing landscapes of the past in class subjectivity: practices of memory and distinction in marketizing Russia. American Ethnologist 36(1): 79-95.

Robinson V and Hockey J (2011) Masculinities in Transition. London: Palgrave Macmillan.

Rosstat (2012) Sredniaia nachislennaia zarabotnaia plata muzhchin i zheshchin po obsledovanym vidam ekonomicheskoi deiatel'nosti. Available at:

www.gks.ru/wps/wcm/connect/rosstat/rosstatsite/main/population/wages/\#

Savage M (2003) A new class paradigm? British Journal of Sociology of Education 24(4): 535-41

Sidel'kovskii A (2007) Kolledzhy, Tekhnikumy i Professional'nie Uchilishcha Sankt-Peterburga i Leningradskoi Oblasti 2007-8. Saint Petersburg: Intermedika.

Stella F (2013) Lesbian lives and real existing socialism in late Soviet Russia. In: Taylor Y and Addison M (eds) Queer Presences and Absences. Series: Gender and sexualities in the social sciences. Palgrave MacMillan, Basingstoke

Skeggs B (1997) Formations of Class and Gender: Becoming Respectable. London: Sage.

Skeggs B (2005) The Making of Class and Gender through Visualizing Moral Subject Formation. Sociology 39(5): 965.

Skeggs B (2011) Imagining personhood differently: person value and autonomist working-class value practices. The Sociological Review 59(3): 496-513.

State University of Service and Economics (2012) Put' k uspekhu nachinaetsya zdes! Available at: http://service.in.spb.ru/abiturientu-glavnaja-stranica/ 
Stenning A (2005) Where is the post-socialist working class?: Working-class lives in the spaces of (post-)socialism. Sociology 39(5): 983-99.

Stephenson SA (2012) The violent practices of youth territorial groups in Moscow. Europe-Asia Studies 64(1): 69-90.

Tartakovskaia I and Ashwin S (2006) Who benefits from networks? In: Ashwin S (ed) Adapting to Russia's New Labour Market: Gender and Employment Strategy. London: Routledge, 164-92.

UNDP (2004) Human Development Report, Russian Federation, 2004: Towards a Knowledge-Based Society. Moscow: United Nations Development Programme.

Walker C (2011) Learning to Labour in Post-Soviet Russia: Vocational Youth in Transition. London: Routledge.

Walkerdine V, Lucey H and Melody J (2001) Growing up Girl: Psychosocial Explorations of Gender and Class. Basingstoke: Palgrave.

Walkerdine V (2003) Reclassifying Upward Mobility: Femininity and the neo-liberal subject. Gender and Education 15(3): 237-48.

Warhurst C, Nickson D, Witz A and Cullen AM (2000) Aesthetic labour in interactive service work: some case study evidence from the 'new' Glasgow. The Service Industries Journal 20(3): 1-18.

\section{Biography}

Charlie Walker is Lecturer in Sociology at the University of Southampton, UK, and Honorary

Research Associate at the School of Slavonic and East European Studies, University College London, UK. He is author of Learning to Labour in Post-Soviet Russia: Vocational Youth in Transition (Routledge, 2011) as well as numerous articles and book chapters addressing the changing shape of youth and transformations of class and gender in the post-Soviet space. He is also co-editor of Youth and Social Change in Eastern Europe and the Former Soviet Union (Routledge, 2012) and Innovations in Youth Research (Palgrave, 2011). 